\title{
Effect of a Pipe Number on The Heat Transfer Rate for a Granite Stone Absorber Solar Collector
}

\author{
M. Mirmanto*, M. Wirawan, B.H. Saputra \\ Teknik Mesin Fakultas Teknik Universitas Mataram, Jln. Majapahit No.62 Mataram, NTB 83125 \\ *E-mail : m.mirmanto@unram.ac.id
}

\begin{abstract}
As the fossil energy has been getting depletion, it is important to utilize alternative energies such as solar energy. An equipment that can be used for capturing and converting solar energy is solar collector. Two identical collectors used in this study were placed facing to the North with an inclination angle of $15^{\circ}$. The collector dimension was $0.8 \mathrm{~m} \times 1 \mathrm{~m} \times 0.05 \mathrm{~m}$. One collector contained 5 parallel pipes and the other contained 7 parallel pipes. The water used in the test was flowed naturally due to the gravity force from a higher tank and was adjusted using a valve fitted at the end of the collector. The water flow rates employed were 200, 250 and $300 \mathrm{cc} /$ minutes and measured using a volume meter and a stop watch. The results showed that the energy coming into the collector, energy absorbed by the absorber and water, increased with an increase in the observation time and reached the peak value at about $2.30 \mathrm{pm}$. After that, they decreased. The effect of the pipe number is insignificant.
\end{abstract}

Keywords: solar collector, stone granite absorber, collector performance.

\begin{abstract}
Abstrak
Sebagaimana energi fosil telah mulai berkurang, maka sangat penting untuk memanfaatkan energi alternatif seperti energi surya. Suatu peralatan yang dapat digunakan untuk menangkap dan mengubah energi surya adalah kolektor surya. Dua kolektor surya identik digunakan dalam penelitian ini ditempatkan menghadap ke Utara dengan sudut kemiringan $15^{\circ}$. Dimensi kolektor adalah 0,8 $\mathrm{m} \times 1 \mathrm{~m} \times 0,05 \mathrm{~m}$. Salah satu kolektor yang terdiri dari 5 pipa paralel dan lainnya yang terdiri dari 7 pipa paralel. Air yang digunakan dalam percobaan ini mengalir secara alami karena gaya gravitasi dari tangki yang lebih tinggi dan diatur dengan katup dipasang pada sisi keluaran kolektor. Laju aliran air yang digunakan adalah 200, 250 dan 300 cc / menit dan diukur dengan menggunakan gelas ukur dan stop watch. Hasil penelitian menunjukkan bahwa energi yang masuk ke kolektor, energi yang diserap oleh absorber dan air, naik dengan meningkatnya waktu observasi dan mencapai nilai puncak pada sekitar pukul 02:30 Wita. Setelah itu, menurun. Pengaruh jumlah pipa adalah tidak signifikan.
\end{abstract}

Kata kunci: kolektor surya, absorber batu granit, performa kolektor

\section{INTRODUCTION}

Energy is something that is always needed for human survival. In all conditions human requires or uses energy . However, most human life still depends on fossil energy. Fossil energy such as petroleum and coal is an energy source that cannot be renewed. Therefore, efforts to conserve energy and utilize alternative energy are required. One of the alternative energies is solar energy.

Solar energy is one of the renewable energies that is cheap and free and it has high potencies to be used. The use of solar energy in Indonesia is really suitable because Indonesia is a region that locates under the equator and between $6^{\circ} \mathrm{NL}$ and $11^{\circ} \mathrm{SL}$. In this position, Indonesia has a tropical weather and sun rays along the day spread uniformly. Therefore, Indonesia has solar energy with a radiation intensity of about $1000 \mathrm{~W} / \mathrm{m}^{2}$ or almost $4.8 \mathrm{kWh} / \mathrm{m}^{2}$ a day,
Rahardjo and Fitrianan [1].

To increase the effectiveness of solar energy use, a device called solar collector can be utilized. This device can be used for converting solar energy to be useful energy. One type of this device is flat plate solar collector. In general, from the view point of capturing the solar energy, collectors are grouped into two types: (i) concentrating collector and (ii) non-concentrating collector. For the nonconcentrating collector, the absorber area is the same as the aperture, Lunde [2].

The collectors used in this study are nonconcentrating collectors, they are flat plate collectors with granite stone absorbers. Generally, solar collectors use metallic absorbers to absorb the solar heat. However, in this paper, the authors wanted to know if the granite stone could be used as an absorber. So the main objective of this study is not to compare the performance of the metallic absorber to 
the granite stone absorber, but just to know the performance of the granite stone as an absorber of a flat plate solar collector. The previous study conducted by Jatmiko [3] reported that granite stone absorber gave better performances than sand absorber. The differences between the current study and the study of Jatmiko [3] are bigger dimension of the collector and the number of the pipe, while in Jatmiko [3], they used pipes arranged in a serpentine form.

When the sun rays falls down on the absorber of a collector, part of the sun energy is reflected to the ambient and other part absorbed by the absorber and converted into useful energy.

Heat energy absorbed by the absorber is transferred to the fluid flowing inside the pipes mounted in the absorber. Finally, the heat can be used for other purposes, Permana and Nasbey [4].

The main components of the flat plate collector as also mentioned in Permana dan Nasbey [4] are:

1. Cover. This component is functioned to reduce the heat lost from the top of the absorber in convection ways.

2. Absorber. This component is used for absorbing the solar heat from the solar radiation.

3. Pipe. This is to transfer the heat from the absorber to the working fluid.
4. Isolator (insulation). This component is employed to minimize the heat loss though the walls in conduction manners.

\section{FACILITY AND EXPERIMENTAL SETUP}

This study uses two prototypes of the flat plate collector with absorbers made of granite stone. All variables were recorded directly unless some calculated variables.

\section{Tools and Materials}

Tools or instruments used were:

1. Thermocouple. Thermocouples used were $\mathrm{K}$ type with measuring ranges ranging from $-200^{\circ}$ to $+1200^{\circ} \mathrm{C}$. These thermocouples were used to know the temperatures of the glass cover, absorber, collector walls, ambient, inlet and outlet of the water.

2. Glass volume meter and stopwatch. These tools were utilized for measuring the volumetric rate of the water.

3. Compass. A compass was used to determine the North-South direction. This was to know the position of the sun so that the collectors could be placed correctly.

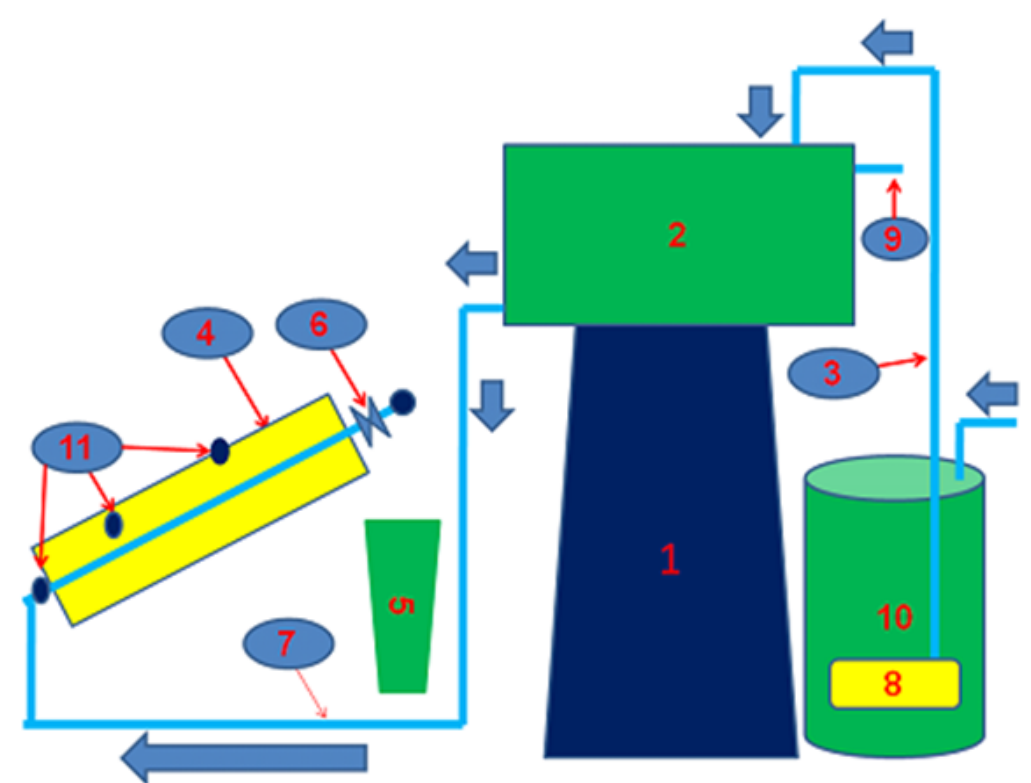

Description (1) tower, (2) plastic bucket, (3) PVC plastic, (4) flat plate collector, (5) glas volume meter, (6) valve to adjust the volumetric rate, (7) flexible plastic pipe, (8) pump, (9) over flow pipe, (10) lower plastic bucket, (11) thermocouple.

Figure 1. Schematic diagram of the experimental apparatus 
4. Pump. The pump was used for raising the water from the well to the top reservoir.

Materials employed in this study were granite stone, water, sterofoam, collector frame, plastic buckets, copper pipes, flexible plastic pipes. The schematic diagram of the research is shown in figure 1 comprising a tower, plastic buckets, a flexible plastic pipe, flat plate collectors, a glass volume meter, valves, a pump, an over flow pipe and thermocouples. The water flowed from the upper plastic bucket (2) through the flexible plastic pipe (7). At the collector entrance and exit, the temperature of water was measured. The water
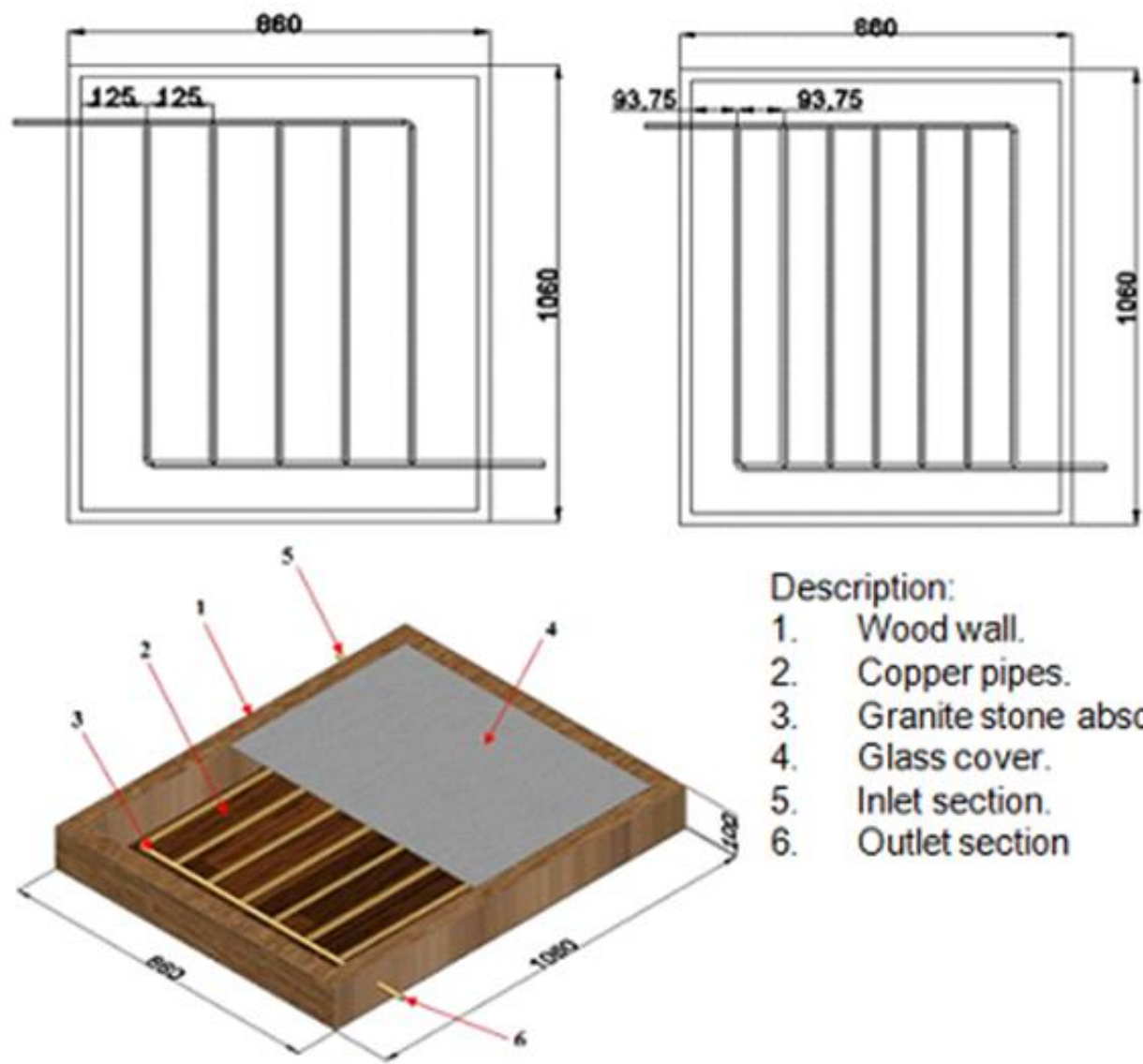

Where $q_{u s e}$ is the useful energy, $c_{p}$ is the specific heat which can be attained in the fluid property table based on the bulk temperature $\left(T_{i}+T_{o}\right) / 2$, $\dot{m}$ represents the mass flow rate of the working fluid conduction, convection, radiation equations and Newton Law of cooling which can be obtained in Holman [5]:

$$
q_{u s e}=\dot{m} c_{p}\left(T_{o}-T_{i}\right)
$$

\section{Description:}

1. Wood wall.

2. Copper pipes.

3. Granite stone absorber.

4. Glass cover.

5. Inlet section.

6. Outlet section

Figure 2. Flat plate solar collector construction

received the heat from the absorber/pipe. Measuring the volumetric rate of the water was performed at the outlet of the collector using the glass volume meter and the stopwatch. Meanwhile, the test section construction is presented in figure 2 .

All temperatures were measured using calibrated type $\mathrm{K}$ thermocouples with an uncertainty of $\pm 0,5^{\circ} \mathrm{C}$. The volumetric rates used were 200,250 and $300 \mathrm{cc} /$ minute measured using the glass volume meter and stopwatch. which can be predicted using equation (2).

$$
\dot{m}=\rho A V
$$

Where $\rho$ is the fluid density, $A$ is the cross sectional area, $V$ is the mean fluid velocity inside the duct.

Heat received by the collector, $q_{i}$, can be estimated as:

$$
q_{i}=I_{T} A_{c}
$$


Where $I_{T}$ is the energy intensity of the solar radiation which can be detected using a pyranometer and $A_{c}$ is the area of the collector absorber or aperture, see Holman [5]. The heat loss to the ambient, $q_{\text {loss }}$, is determined as:

$$
q_{\text {loss }}=q_{i}-q_{\text {use }}
$$

One indicator representing the performance of the collector is a collector efficiency which is defined as a comparison between the useful energy and the heat coming and given by:

$$
\eta=\frac{q_{\text {use }}}{q_{\text {in }}}
$$

\section{RESULTS AND DISCUSSIONS}

Using equation (1) results in calculated useful energy data, $q_{\text {use }}$, which are presented in figure 3 . The data were obtained from the experiments at the volumetric rates of 200,250 and $300 \mathrm{cc} /$ minute. In figure 3 , it is clear that effect of the pipe number on the heat transfer rate is insignificant because the lines indicating the useful energy are touching each other for both collectors (5 pipes and 7 pipes). This phenomenon occurs at all the tested volumetric rates. If they are calculated using a percentage of the useful energy deviation, their difference is still very small. For example, at the volumetric flow rate of 200 $\mathrm{cc} /$ minute, their deviation is only $5,87 \%$, at the 250 $\mathrm{cc} /$ minute, it is $4,1 \%$ and at the $300 \mathrm{cc} /$ minute the deviation is about $2,5 \%$, see figure 4 . Based on the acceptable error theory written by Adebayo and Osmond [6], Sommer and Kochsiek [7], the deviations here are less than $10 \%$, therefore, the deviations can be negligible. In another word, the deviations do not represent the effect of the pipe number on the heat transfer rate. One of the causes of this phenomenon is due to the same collector area, so that the energy received by the absorber is the same, consequently energy absorbed the water is also the same. Of course, there is a difference of the pipe heat transfer area for 5 pipe and 7 pipe collectors, however, the pipe heat transfer is to small compared to the heat transfer area of the collector, hence, the difference of the pipe heat transfer area is not enough to make significantly deviations. Therefore, the effect of the pipe number on the heat transfer rate is insignificant. Similarly, from the view point of the useful energy, see figure 4 , the number of the pipe does not show different useful energy. Nevertheless, in figure 3 , It seems that the useful energy for both 5 pipe and 7 pipe collectors is higher at the volumetric rate of $250 \mathrm{cc} /$ minute. This was due to the different solar radiation energy received by the collectors. The three different volumetric rates were tested on the different days, when the $250 \mathrm{cc} /$ minute was being tested the solar radiation energy was higher,
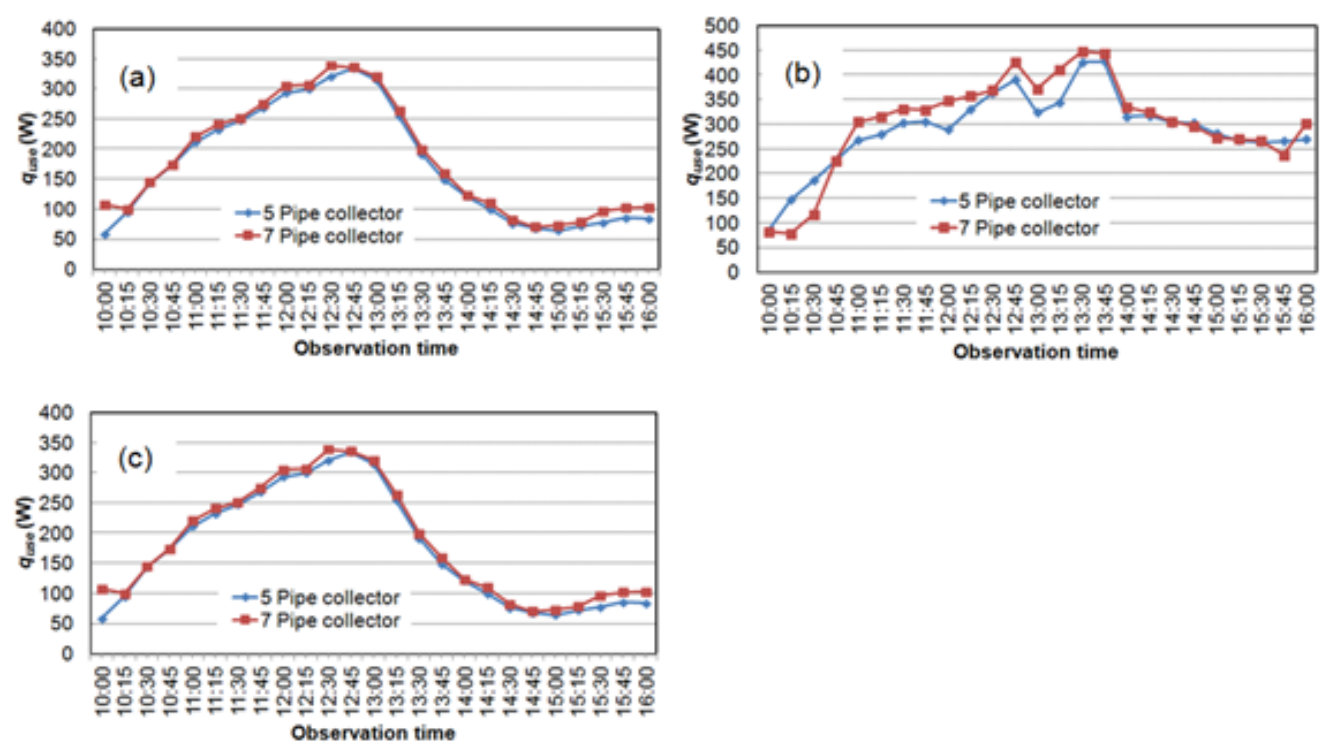

Figure 3. Useful energy $q_{u s e}$ versus observation time; (a) $200 \mathrm{cc} /$ minutes, (b) $250 \mathrm{cc} /$ minutes, (c) $300 \mathrm{cc} /$ minutes 

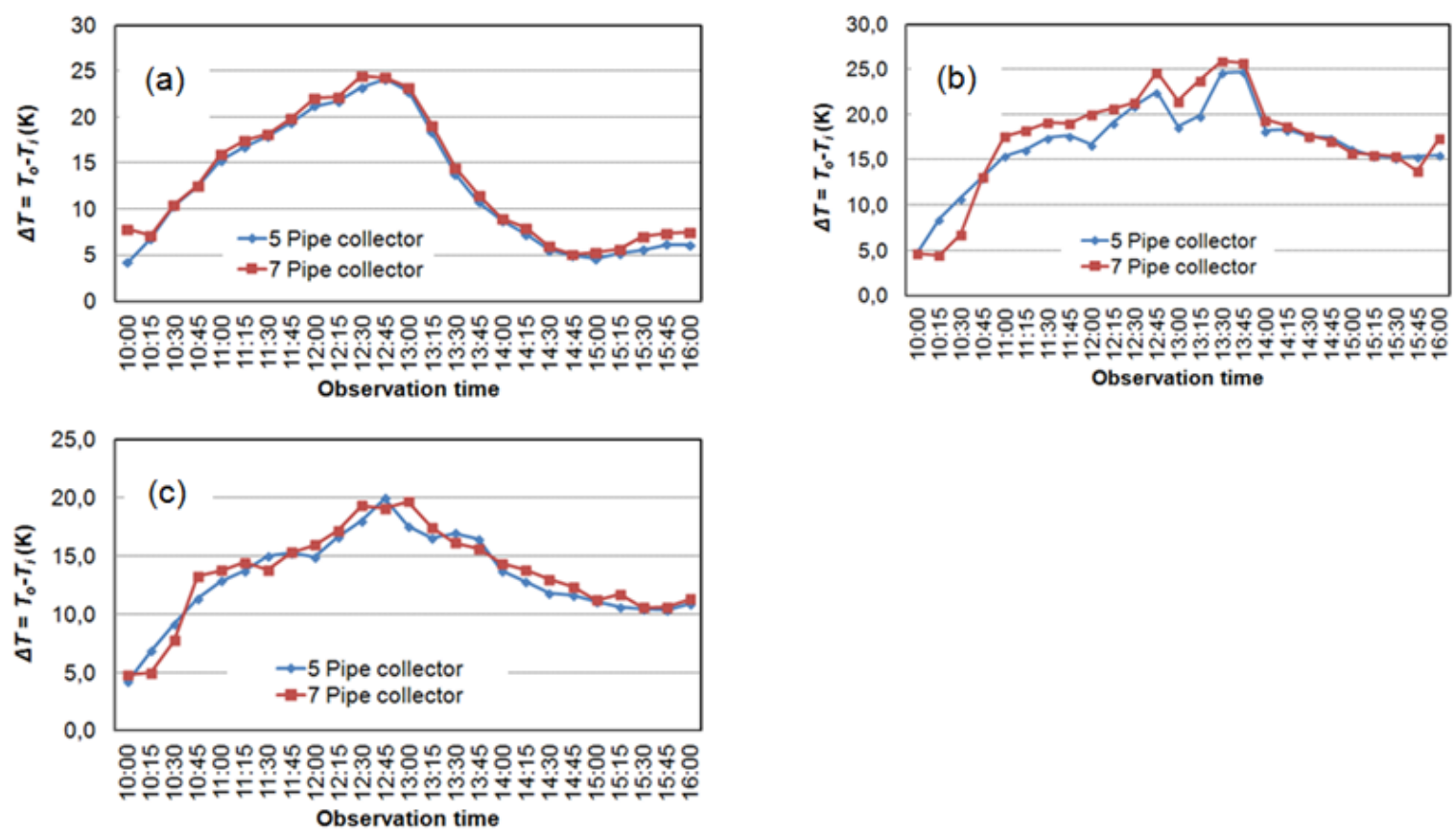

Figure 4. Water temperature increase, $\Delta T$, versus observation time; (a) $200 \mathrm{cc} /$ minutes, (b) $250 \mathrm{cc} /$ minutes, (c) $300 \mathrm{cc} /$ minutes
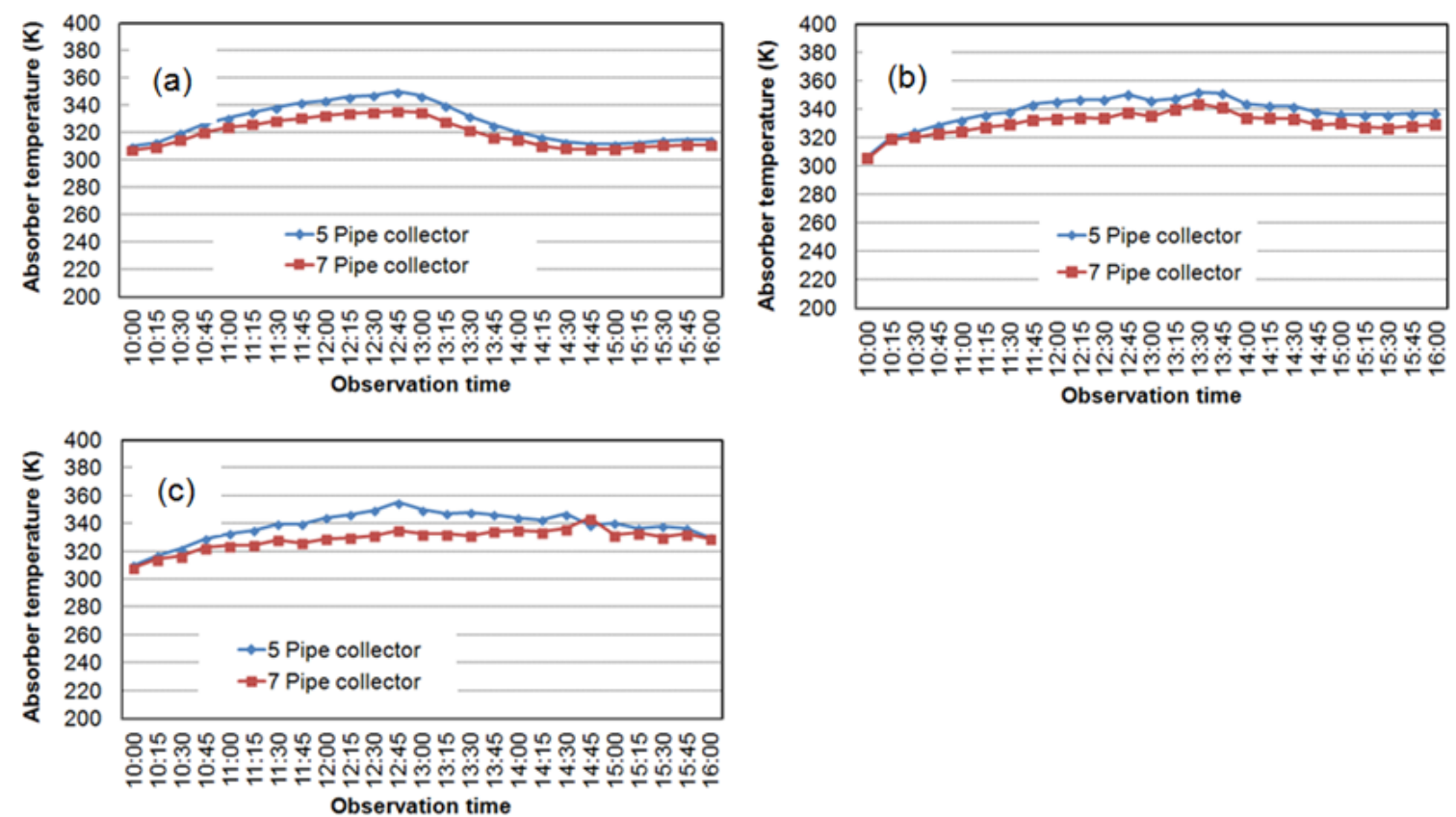

Figure 5. Water temperature versus observation time; (a) $200 \mathrm{cc} /$ minutes, (b) 250 $\mathrm{cc} /$ minutes, (c) $300 \mathrm{cc} /$ minutes

consequently at the $250 \mathrm{cc} /$ minute the useful energy is higher than those at the other two volumetric rates.

Another result relating to the useful energy is the water temperature increase. The increase of the water temperature is presented in figure 4 . From the figure, it can be seen that the increase of the water 


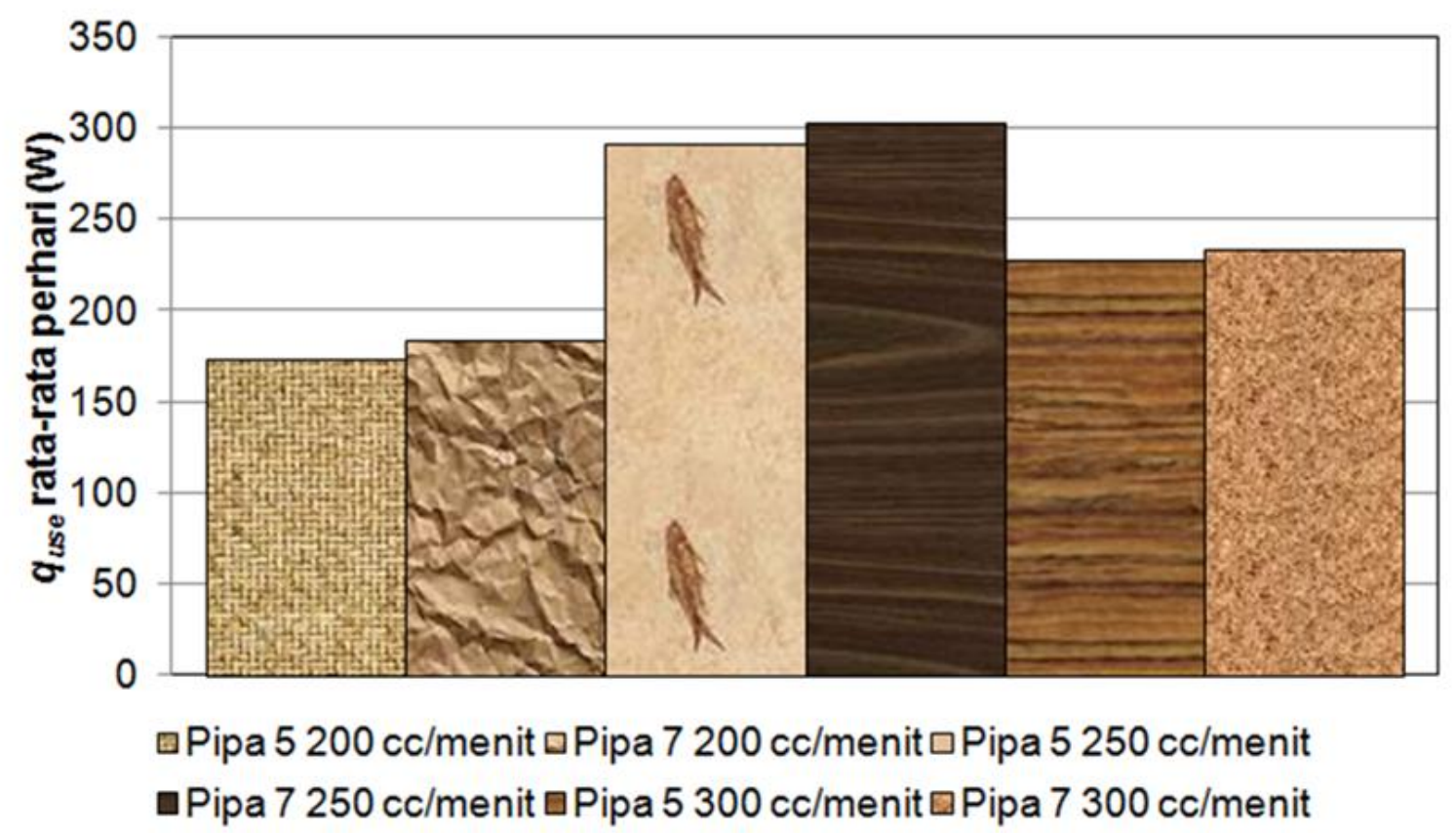

Figure 6. Daily average useful energy

temperature for the two solar collectors at the same volumetric rate is not significant. This is one of the factors that causes no different useful energy for both collector. The useful energy is only a function of the water temperature if the specific heat and the mass

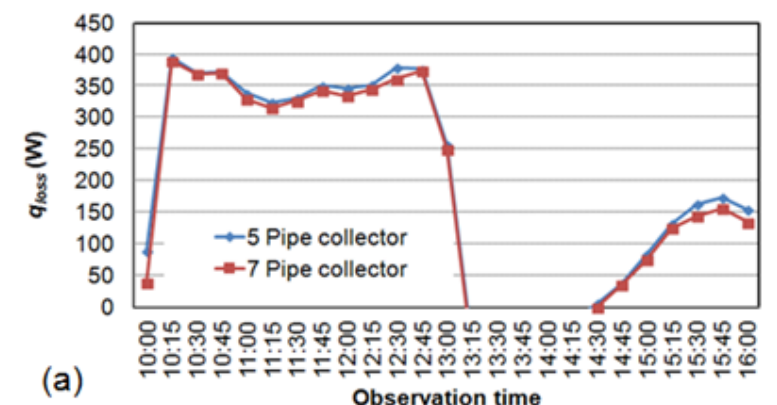

(a)

Observation time

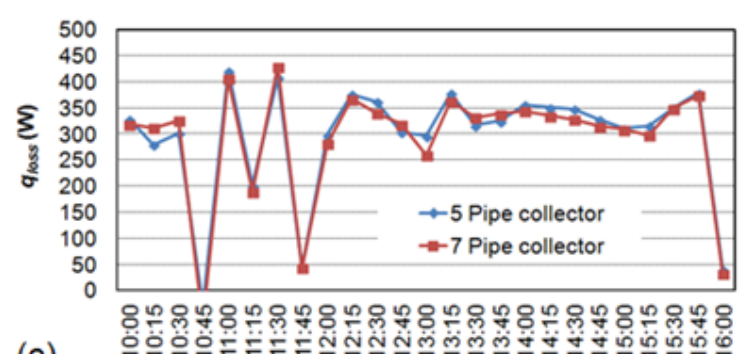

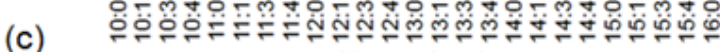

flow rate is the same. Therefore, the graph of the useful energy trend (figure 3 ) is almost the same as the graph of the water temperature increase (figure 4).

Absorber temperatures are important thing in

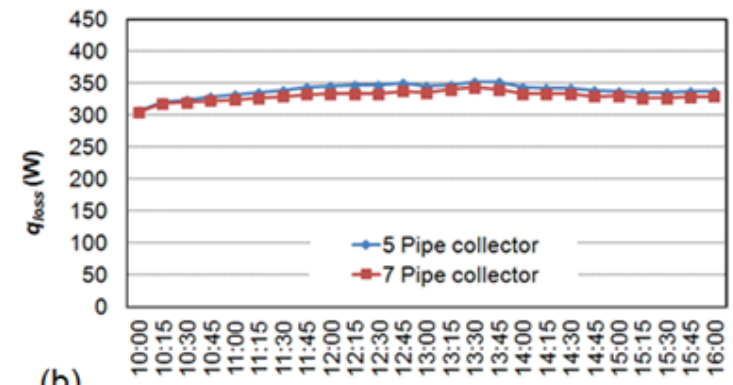

(b)

Observation time

Figure 7. Heat loss versus observation time; (a) $200 \mathrm{cc} /$ minutes, (b) $250 \mathrm{cc} /$ minutes,

(c) $300 \mathrm{cc} /$ minutes 
the solar water heater. They relate the heat loss to the ambient. The higher absorber temperature results in the higher heat loss and the lower useful energy. The absorber temperatures obtained from the experiments are presented in figure 5 .

In figure 5 it seems that the absorber
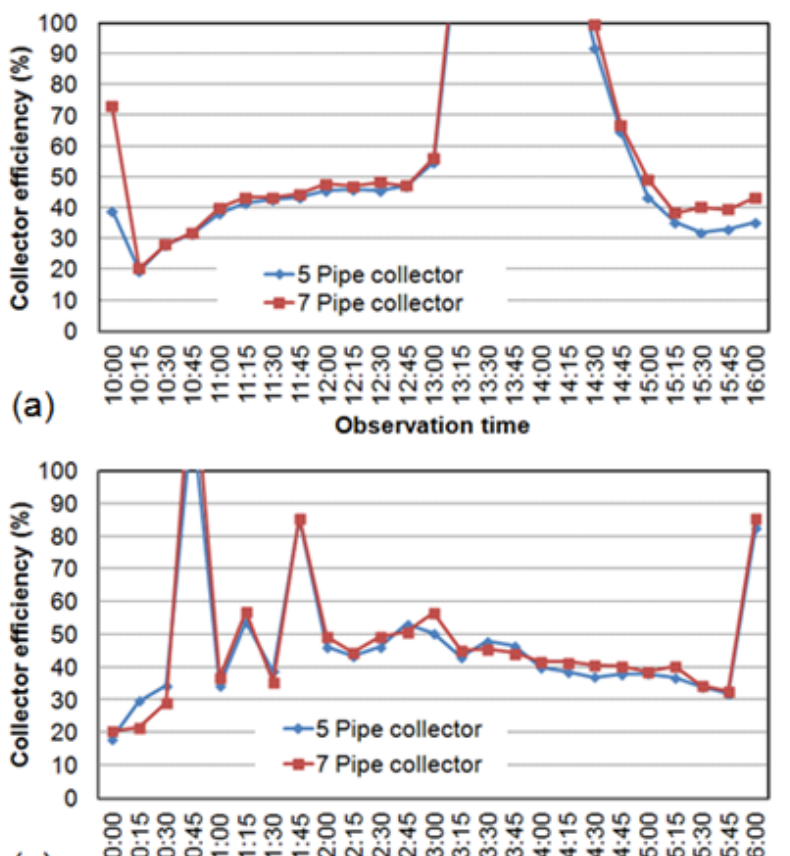

(c) in the lowest heat loss.

One important parameter in testing the solar collector is the collector efficiency. Theoretically, the efficiency of the collector can be predicted using equation (5) and the results are shown in figure 8. The collector efficiency is affected by the useful

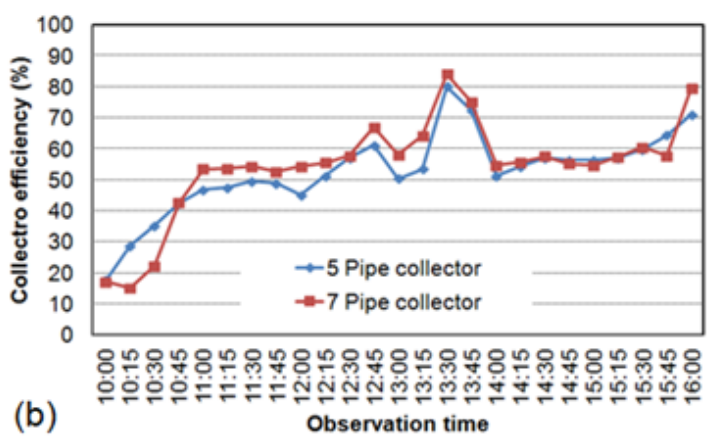

Figure 8. Collector efficiency versus observation time; (a) $200 \mathrm{cc} /$ minutes, (b) 250 cc/minutes, (c) $300 \mathrm{cc} / \mathrm{minutes}$

temperature for the 5 pipe collector is always higher than the absorber temperature for the 7 pipe collector. This was due to the lower energy absorbed by the water in the 5 pipe collector. Even so, the difference of the useful energy for both collectors is still below $10 \%$ or insignificant due to [6,7]. However, the average daily useful energy for the 7 pipe collector is higher than that for the 5 pipe collector, as seen in figure 6. Energy received by the collector is surely the same because the collector area is the same, nevertheless, the heat loss for the 5 pipe collector is higher than that of the 7 pipe collector. To know the heat loss to the ambient, figure 7 is presented.

Figure 7 indicates the heat loss to the ambient for the 5 pipe collector is higher than that for the 7 pipe collector. This can be seen that the blue line is almost always above the red line. Figure 7 confirms the explanation given by the figure 5. Figure 7(a) shows a different phenomenon. That was due to the condition of the sky. When the sky is cloudy, the sun energy coming into the collector is small, meanwhile the useful energy is still big because of the saved energy in the absorber than can be removed by the water. For that reason, applying equation (4) results energy and incoming energy, therefore, the efficiency of the collector when the sky is cloudy, is very high, see figure $8(a)$. This is due to the very low incoming energy when the sky is not clear, while the useful energy remains high, consequently, the efficiency is very high.

\section{CONCLUSIONS}

Base on the experimental results and discussion, several conclusions can be drawn as follows:

1. The effect of the pipe number on the heat transfer rate is insignificant.

2. The heat transfer rate is affected by the observation time.

3. The heat loss to the ambient is influenced by the absorber temperature.

4. The effect of the volumetric rate on the heat transfer rate is inconclusive. 


\section{ACKNOWLEDGEMENT}

The authors would like to acknowledge the Mataram University for the funding (BOPTN research grand) and the facility.

\section{NOMENCLATURE}

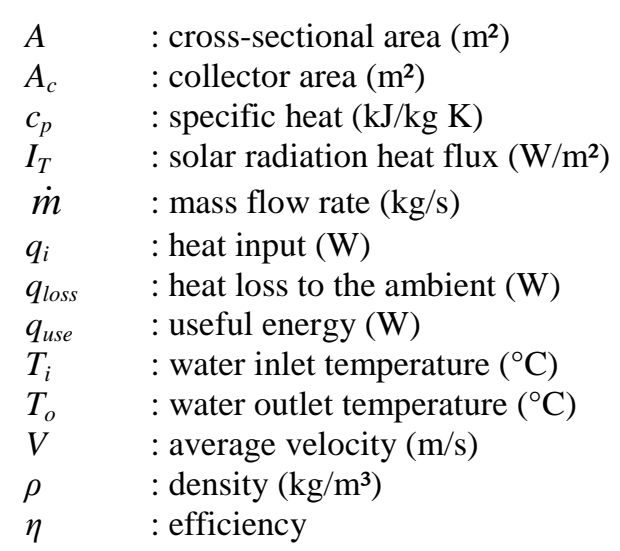

\section{REFERENCES}

[1] I. Rahardjo, I. Fitriana, Analisis potensi pembangkit listrik tenaga surya di Indonesia, strategi penyediaan listrik nasional dalam rangka mengantisipasi pemanfaatan PLTU batubara skala cecil, PLTN dan Energi Terbarukan, 2000.

[2] J.P. Lunde, Solar Thermal Engineering, John Wiley \& Sons, New York, 1980.

[3] H. Jatmiko, Kajian eksperimental penggunaan absorber pasir dan absorber batu granit terhadap laju perpindahan kalor yang diterima air pada kolektor surya tipe plat datar, Tugas Akhir, Teknik Mesin, Fakultas Teknik, Universitas Mataram, 2014.

[4] H. Permana, H. Nasbey, Preparasi pengukuran suhu kolektor surya dan fluida kerja dengan datapaq easytrack 2 system, Jurnal Fisika dan Aplikasi (2011).

[5] J.P. Holman, Heat Transfer, 8th edition, McGraw-Hill Companies, Inc., USA, 1997.

[6] O.O. Adebayo, I.C. Osmond, A search for an acceptable margin of valuation error: A case study of valuers and their clients in Nigeria, Sri Lankan Journal of Estate, Department of Estate Management Valuation University of Sri Jayewardenepura, Sri Lanka, 54-73.

[7] K.D. Sommer, M. Kochsiek, Role of measurement uncertainty in deciding conformance in legal metrology, in Proc. of The 10th Int. Metrology Congress, Saint Louis, France, 22-25 October 2001. 